\title{
The Application of Polyethylene Glycol Precipitation for Purification of Potato Leaf-Roll Virus
}

\author{
Makoto Kojima* and Daiki Murayama* \\ 小島 誠*・村山大記*：ポリエチレングリコールによる \\ ジャガイモ葉巻病ウィルスの沈澱
}

A large scale purification is required for biochemical and biophysical research of aphid-borne circulative plant viruses, because of the low virus content in the host plants. The current procedure for purification of potato leaf-roll virus (PLRV) from plant materials is fairly laborious ${ }^{1)}$. Since Hebert $^{2}$ ) reported polyethylene glycol (PEG) precipitation of plant viruses, many workers have applied this PEG precipitation for purifications of bacteriophages and animal viruses ${ }^{3,4)}$. We have applied PEG precipitation to PLRV, as a modification of the purification procedure described previously ${ }^{1}$.

In preliminary experiments, assays by aphid-injection showed that precipitates obtained by the addition of 4 or $8 \%$ PEG to clarified plant juice retained infectivity. However, the amount of virus in the precipitates could not be accurately measured by the bioassay. Accordingly, comparative assays using precipitates obtained by the addition of PEG at various concentrations were made by an analytical sucrose density-gradient centrifugation ${ }^{5)}$.

Frozen tissue of Physalis floridana plants infected with PLRV was ground by an electric meat grinder. The macerate was then homogenized with a Waring Blendor in $0.5 \mathrm{M}$ phosphate buffer (pH 7.4). The homogenate was emulsified with a chloroform and $n$-butanol mixture $(1: 1)$ in a fruit mixer. The preparation was clarified by centrifuging at $6,000 \mathrm{rpm}$ for 15 minutes in $9 \mathrm{~B}-2$ rotor of a Marusan high-speed centrifuge. PEG 6,000 was added at various concentrations to the resultant aqueous phase, which was stirred for 60 minutes and then kept in a centrifuge tube for 60 minutes at room temperature. Precipitates obtained after centrifugation in the same rotor at $6,000 \mathrm{rpm}$ for 15 minutes were suspended in $0.01 M$ phosphate buffer $(\mathrm{pH}$ 7.4) with a chilled Teflon-glass homogenizer. The resuspended preparation was again clarified with fluorocarbon (Daifron S-3) in a cold room, and further purified by two cycles of differential centrifugation (at 40,000 rpm for 120 minutes; at $10,000 \mathrm{rpm}$ for 15 minutes) in RP40 rotor of a refrigerated Hitachi $40 \mathrm{P}$ ultracentrifuge. Two milliliters each of the concentrated preparation (from $400 \mathrm{~g}$ of tissue) was layered on a sucrose gradient column, and was centrifuged at $23,000 \mathrm{rpm}$ for 180 minutes in RPS25 rotor of the same ultracentrifuge. Density-gradient columns, made by layering of 4, 7, 7 and $7 \mathrm{ml}$ of 100, 200, 300 and $400 \mathrm{mg}$ of sucrose per milliliter of phosphate buffer $(0.01 M, \mathrm{pH} 7.4)$, respectively, in $1 \times 3$ inch cellulose nitrate centrifuge tubes, were used after standing overnight at $4^{\circ} \mathrm{C}$. For an analytical density-gradient centrifugation, centrifuged columns were scanned with an ISCO gradient column fractionator and flow densitometer attached with an external recorder.

A $10 \mathrm{~mm}$ light path cell and sensitivity range $0-0.5$ at $253.6 \mathrm{~nm}$ wavelength were used. Scanning patterns of the centrifuged gradient columns on which partially purified preparations using PEG at

* Faculty of Agriculture, Hokkaido University, Sapporo, Japan. 北海道大学農学部

1) Kojima, M., Shikata, E. Sugawara, M., and Murayama, D. (1969). Virology 39: 162. 2) Hebert, T. T. (1963). Phytopathology 53: 362. 3) Yamamoto, K. R., Alberts, B. M., Benzinger, R., Lawhorne, L. and Treiber, G. (1970). Virology 40:734. 4) McSharry, J. and Benzinger, R., (1970). Virology $40: 745$. 5) Brakke, M. K. (1963). Anal. Biochem. 5: 271. 
various concentrations were layered are shown in Fig. 1. The scanning pattern did not show an extra component at $25-27 \mathrm{~mm}$ from the meniscus, when partially purified preparation obtained by using 4\% PEG was layered. However, scanning patterns with a peak were obtained when preparations obtained from 6,8 and $10 \%$ PEG precipitates were layered. In these gradient columns, a zone visible by scattered light was observed at $25-27 \mathrm{~mm}$ from the meniscus. These patterns suggested that PLRV was partially precipitated by the addition of $6 \%$ PEG, and completely by $8 \%$ PEG. On the other hand, the scanning pattern did not have a peak at $25-27 \mathrm{~mm}$ from the meniscus when preparation obtained from healthy P. floridana plants with 8\% PEG was layered (Fig. 1).

Fig. 2 shows scanning pattern obtained from an experiment with the same purification procedure as described above, using $8 \%$ PEG to precipitate virus from 1,000 g of starting material. This pattern indicates that the sedimentation rate of PLRV would be greater than that of barley yellow dwarf

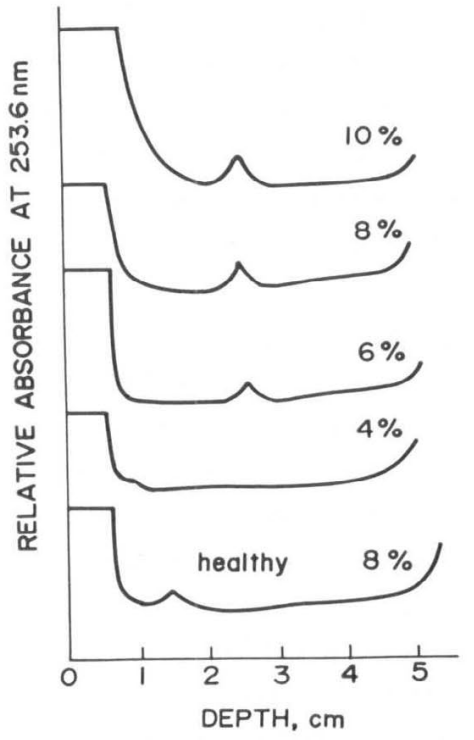

Fig. 1. Scanning patterns of gradient columns centrifuged after layering $2 \mathrm{~m} l$ each of partially purified preparations of potato leaf-roll virus concentrated by PEG precipitation at various concentrations, followed by two cycles of differential centrifugation. The columns, prepared from $4,7,7$ and $7 \mathrm{ml}$ of $100,200,300$ and $400 \mathrm{mg}$ sucrose per milliliter, respectively, were centrifuged at 23,000 rpm for 180 minutes. These tubes were scanned with a $10 \mathrm{~mm}$ light path and sensitive range $(0-0.5)$ of densitometer.

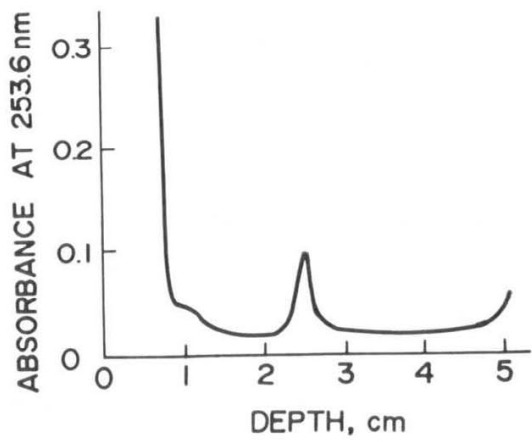

Fig. 2. Scanning pattern of gradient column centrifuged after layering of $2 \mathrm{ml}$ of partially purified preparation of potato leaf-roll virus concentrated $500 \times$ i. e, $2 \mathrm{~m} l$ from $1,000 \mathrm{~g}$ infected plant tissues) by $8 \%$ PEG precipitation followed by two cycles of differential centrifugation. Columns were centrifuged for $180 \mathrm{~min}$ utes at 23,000 rpm.

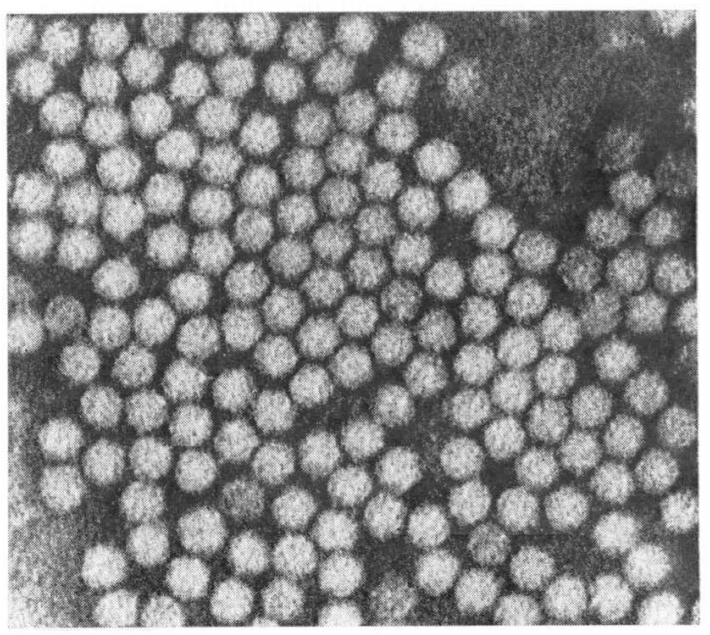

Fig. 3. Electron micrograph of phosphotungstate-stained PLRV $(\times 150,000)$. 
virus (115-118 S), based on comparison of the present result with those of Rochow and Brakke6). The yield of purified virus from $1,000 \mathrm{~g}$ of infected plants was about $10 \mu \mathrm{g}$, assuming an $\mathrm{A}_{260}$ of 5.0 for a $1 \mathrm{mg} / \mathrm{m} l$ concentration.

It was confirmed that this peak region was associated with infectivity and contained many uniform virus particles (Fig. 3).

The results obtained here suggest that the PEG precipitation method may be useful as the first step to facilitate purification of aphid-borne plant viruses.

\section{Acknowledgement}

The authors are indebted to Dr. M. K. Brakke for his critical comments of the manuscript. (Received June 23, 1972) 